\title{
COMPARATIVE STUDY OF EXTREMELY LOW BIRTH WEIGHT BABIES (ELBW) VERSUS VERY LOW BIRTH WEIGHT BABIES (VLBW) TILL ONE YEAR OF CORRECTED AGE IN TERMS OF GROWTH
}

\author{
Jeethu Thampi Jayasree ${ }^{1}$, Darly Saramma Mammen², Deepa Kunju Krishnan³, Suresh Sebastian Vadakkedam ${ }^{4}$ \\ 1 Junior Resident, Department of Paediatrics, Government Medical College, Kottayam, Kerala, India. \\ ${ }^{2}$ Associate Professor, Department of Paediatrics, Government Medical College, Kottayam, Kerala, India. \\ ${ }^{3}$ Assistant Professor, Department of Paediatrics, Government Medical College, Kottayam, Kerala, India. \\ ${ }^{4}$ Assistant Professor, Department of Paediatrics, Government Medical College, Kottayam, Kerala, India.
}

\section{ABSTRACT}

\section{BACKGROUND}

Wide-ranging differences in growth exist between full-term babies born with normal weight and those born prematurely. With the exception of infants with severe impairment, infants weighing less than 1500 grams are likely to remain smaller than their normal weight peers at adolescence. WHO defines low birth weight infants as those born with birth weight less than 2500 grams. It is further subdivided into Very Low Birth Weight (VLBW) babies: Birth weight $<1500$ grams and Extremely Low Birth Weight (ELBW) babies: Birth weight $<1000$ grams.

Aim- To compare the growth of VLBW babies versus ELBW babies till one year of corrected age.

\section{MATERIALS AND METHODS}

Partially cohort study design in which 60 babies in two groups; Group 1 of 30 babies (extremely low birth weight, i.e. < 1000 gms) and Group 2 of 30 babies (very low birth weight, i.e. $<1500$ gms) were followed up till one year of corrected age. Follow-up was done at $3^{\text {rd }}, 6^{\text {th }}, 9^{\text {th }}$ and $12^{\text {th }}$ month of corrected age.

\section{RESULTS}

In this study of total 60 neonates, 30 were ELBW babies and 30 were VLBW babies. In this study, the mean birth weight of ELBW babies was 870 grams and mean birth weight of VLBW babies was $1.2 \mathrm{~kg}$. In this study, there exists a significant difference in the Gestational age of babies in the ELBW and VLBW group. In the ELBW group babies, mean gestational age was 29 weeks which was less than the gestational age of babies in VLBW group, which was 30.03 weeks. On the follow-up of growth at 12 months of corrected age, babies who weighed less than $3^{\text {rd }}$ centile consisted of 73.1\% of ELBW babies and 26.9\% of VLBW babies. There was statistical difference between two groups. At 12 months of corrected age, babies whose length was less than $3^{\text {rd }}$ centile consisted of $53.8 \%$ of ELBW babies and $46.2 \%$ of VLBW babies, which was statistically insignificant. During follow-up at 12 months of corrected age, babies whose head circumference was less than $1^{\text {st }}$ centile consisted of 54.5\% of ELBW babies and $45.5 \%$ of VLBW babies which was statistically insignificant.

\section{CONCLUSION}

In this study, on comparing the two groups the growth of ELBW babies faltered more compared to their VLBW counterparts during this one-year follow-up study.

\section{KEY WORDS}

ELBW, VLBW, Length, Weight, Head Circumference.

HOW TO CITE THIS ARTICLE: Jayasree JT, Mammen DS, Krishnan DK, et al. Comparative study of extremely low birth weight babies (ELBW) versus very low birth weight babies (VLBW) till one year of corrected age in terms of growth. J. Evolution Med. Dent. Sci. 2018;7(42):4571-4575, DOI: 10.14260/jemds/2018/1019

\section{BACKGROUND}

WHO defines low birth weight infants as those born with birth weight less than 2500 grams. ${ }^{1}$ It is further subdivided into-

- Very Low Birth Weight (VLBW) babies: Birth weight < $1500 \mathrm{~g}$.

- Extremely Low Birth Weight (ELBW) babies: Birth weight $<1000 \mathrm{~g}$.

'Financial or Other Competing Interest': None.

Submission 10-08-2018, Peer Review 28-09-2018,

Acceptance 03-10-2018, Published 15-10-2018.

Corresponding Author:

Darly Saramma Mammen,

Associate Professor,

Department of Paediatrics,

Institute of Child Health,

Government Medical College,

Kottayam-686561, Kerala, India.

E-mail: drdarlymammen@gmail.com

DOI: $10.14260 /$ jemds/2018/1019

\section{(c) (1) $(9$}

Wide-ranging differences in growth exist between fullterm (FT) children born with normal birth weight and those born prematurely. With the exception of infants with severe impairment, infants weighing less than $1500 \mathrm{~g}$ are likely to remain smaller. ${ }^{2}$ Infants born at weights categorised as very low birth weight (VLBW: 1000 - $1499 \mathrm{~g}$ ) and extremely low birth weight (ELBW: < $1000 \mathrm{~g}$ ) remain smaller than their normal birth weight peers at adolescence. $3,4,5,6$

Objective- To compare the growth of VLBW babies versus ELBW babies till one year of corrected age.

\section{MATERIALS AND METHODS}

Study Design- Cohort study.

\section{Study Setting}

Tertiary care setting, inborn nursery, outborn nursery and well-baby clinic of Department of Paediatrics, Govt. Medical College, Kottayam. 


\section{Inclusion Criteria}

ELBW and VLBW babies admitted in inborn nursery and outborn nursery.

- $\quad$ ELBW (Birth wt. - < 1000 gm)

- $\quad$ VLBW (Birth wt. - <1500 gm)

\section{Exclusion Criteria}

Babies with chromosomal anomalies and congenital malformations will be excluded from the study.

\section{Methodology}

Consecutive cases satisfying the inclusion criteria and sample size, admitted in inborn and outborn nursery and followed up in well-baby clinic in Dept. of Paediatrics, Govt. Medical College, Kottayam during the study period at 3, 6, 9 and 12 months of corrected age. In this study, the two groups are classified on the basis of weight band alone, i.e. ELBW or VLBW. Their gestational age is not taken into account, hence not further sub-divided into term or preterm LGA, SGA, AGA etc.

\section{Data Management and Analysis}

Data management done using descriptive statistics, inferential statistics along with percentage analysis. Descriptive statistics suggest mean and standard deviation for identifying the preliminary nature of data. Inferential statistics such as Chi-square test and student's t-test used for hypothesis testing. The data was entered in Microsoft Excel and further statistical analysis was done using SPSS software version 22 .

\section{Assessment of Growth}

\section{A. Assessment of Weight}

Birth weight of the baby was recorded after delivery on an electronic weighing machine with an accuracy of measurement of \pm 5 gms ( \pm 5 gms accuracy) in NICU. On follow-up, weight of the baby was recorded on an electronic weighing machine. Underweight is defined as weight less than $3^{\text {rd }}$ centile or less than 2 standard deviations for the age according to WHO growth charts.

\section{B. Assessment of Length}

Infantometer for measuring length; measurement adjusted to nearest $0.1 \mathrm{~cm}$ during every follow-up visit. Stunting defined as length less than 3 rd centile or less than 2 standard deviations according to WHO growth charts.

\section{Assessment of Head Circumference}

Non-stretchable tape to assess head circumference; measurement adjusted to nearest $0.1 \mathrm{~cm}$ during every visit. Microcephaly is defined as head circumference less than $1^{\text {st }}$ centile or less than 3 standard deviation for the age according to WHO growth charts.

This study was designed with an objective to compare the morbidity of ELBW babies versus VLBW babies at birth and to compare the growth of VLBW babies versus ELBW babies till one year of corrected age.

\section{RESULTS}

Total number of infants 60 -

- Total number of infants in ELBW group $=30$

- Total number of infants in ELBW group $=30$

\begin{tabular}{|c|c|c|c|}
\hline & Group & $\mathbf{N}$ & Mean \\
\hline \multirow{2}{*}{ Birth Weight } & ELBW & 30 & .87 \\
\hline & VLBW & 30 & 1.20 \\
\hline
\end{tabular}

The Table 1 shows that ELBW group babies' mean birth weight is $.87 \mathrm{~kg}$ and VLBW babies mean birth weight is $1.2 \mathrm{~kg}$.

\begin{tabular}{|c|c|c|c|c|c|c|}
\hline & Group & $\mathbf{N}$ & Mean & $\begin{array}{c}\text { Std. } \\
\text { Deviation }\end{array}$ & $\mathbf{T}$ & $\begin{array}{c}\mathbf{P} \\
\text { value }\end{array}$ \\
\hline \multirow{2}{*}{$\begin{array}{c}\text { Gestational } \\
\text { Age }\end{array}$} & ELBW & 30 & 29.00 & 1.017 & \multirow{2}{*}{4.35} & \multirow{2}{*}{.000} \\
\hline & VLBW & 30 & 30.03 & .809 & & \\
\hline \multicolumn{7}{|c|}{$\begin{array}{c}\text { Table 2. Data and Result of Significant Difference in the } \\
\text { Gestational Age between Babies in ELBW and VLBW } \\
\text { Group }\end{array}$} \\
\hline
\end{tabular}

The obtained t-value is 4.35 , which is greater than the table value of $1.96(p<0.05)$ at 0.05 level of significance. That means there exists a significant difference in the Gestational age of babies in the ELBW and VLBW group.

\begin{tabular}{|c|c|c|c|c|c|c|}
\hline & Group & $\mathbf{N}$ & Mean & $\begin{array}{c}\text { Std. } \\
\text { Deviation }\end{array}$ & T & $\begin{array}{c}\text { P } \\
\text { value }\end{array}$ \\
\hline $\begin{array}{c}\text { Head } \\
\text { Circumference }\end{array}$ & ELBW & 30 & 27.00 & .830 & 3.37 & .000 \\
\cline { 2 - 6 } & VLBW & 30 & 28.10 & 1.583 & & \\
\hline Table 3. Data and Result of Significant Difference in the \\
Head Circumference at Birth between Babies in ELBW \\
and VLBW Group
\end{tabular}

The obtained $t$-value is 3.37 , which is greater than the table value of $1.96(p<0.05)$ at 0.05 level of significance. That means there exists a significant difference in the Head Circumference of babies in the ELBW and VLBW group.

\begin{tabular}{|c|c|c|c|c|c|c|}
\hline & Group & N & Mean & $\begin{array}{c}\text { Std. } \\
\text { Deviation }\end{array}$ & T & $\begin{array}{c}\text { P } \\
\text { value }\end{array}$ \\
\hline \multirow{2}{*}{ Length } & ELBW & 30 & 37.00 & .871 & \multirow{2}{*}{6.31} & .000 \\
\cline { 2 - 6 } & VLBW & 30 & 40.00 & 2.421 & & \\
\hline Table 4. Data and Result of Significant Difference in the \\
Length at Birth between Babies in ELBW and VLBW \\
Group
\end{tabular}

The obtained t-value is 6.31 , which is greater than the table value of $1.96(\mathrm{p}<0.05)$ at 0.05 level of significance. That means there exists a significant difference in the length of babies in the ELBW and VLBW group.

\section{Follow-Up Analysis}

\begin{tabular}{|c|c|c|c|c|c|}
\hline \multirow[b]{2}{*}{ Group } & & \multicolumn{3}{|c|}{ Weight at $3 \mathrm{~m}$} & \multirow[b]{2}{*}{ Total } \\
\hline & & $\begin{array}{l}<3 \text { rd } \\
\text { Centile }\end{array}$ & $\begin{array}{c}\text { 3rd to } \\
50^{\text {th }} \chi \\
\text { Centile }\end{array}$ & $\begin{array}{c}\text { Greater } \\
\text { than } \\
\mathbf{5 0}^{\text {th }} \\
\text { Centile }\end{array}$ & \\
\hline \multirow{2}{*}{$\begin{array}{l}\text { ELBW } \\
\text { Babies }\end{array}$} & Count & 5 & 16 & 9 & 30 \\
\hline & $\%$ & $25.0 \%$ & $57.1 \%$ & $75.0 \%$ & $50 . \%$ \\
\hline \multirow{2}{*}{$\begin{array}{l}\text { VLBW } \\
\text { Babies }\end{array}$} & Count & 15 & 12 & 3 & 30 \\
\hline & $\%$ & $75.0 \%$ & $42.9 \%$ & $25.0 \%$ & $50 . \%$ \\
\hline \multirow{2}{*}{ Total } & Count & 20 & 28 & 12 & 60 \\
\hline & $\%$ & $100.0 \%$ & $100.0 \%$ & $100.0 \%$ & $100 . \%$ \\
\hline
\end{tabular}

$\mathrm{X}^{2}=8.57, \mathrm{p}=.014(\mathrm{p}<0.05)$. 
Table 5 shows that there is a significant difference between the two groups in weight at 3 months of age $p$-value, $p=.014$ $(\mathrm{p}<0.05)$. Among underweight i.e. $<3^{\text {rd }}$ centile at 3 months of age, $25 \%$ was ELBW babies i.e. 5 babies and $75 \%$ were VLBW babies i.e. 15 babies. Among the babies whose weight fell between $3^{\text {rd }}$ and $50^{\text {th }}$ centile, $57 \%$ were ELBW and $42 \%$ were VLBW. Among the babies who weighed more than 50th centile, $75 \%$ were ELBW and 25\% were VLBW babies.

$\mathrm{X}^{2}=8.44, \mathrm{p}=.015(\mathrm{p}<0.05)$

\begin{tabular}{|c|c|c|c|c|c|}
\hline \multirow[b]{2}{*}{ Group } & & \multicolumn{3}{|c|}{ Weight 12 m } & \multirow[b]{2}{*}{ Total } \\
\hline & & $\begin{array}{c}<3 \text { rd } \\
\text { Centile }\end{array}$ & $\begin{array}{c}\text { 3rd to } \\
50^{\text {th }} \chi \\
\text { Centile }\end{array}$ & $\begin{array}{c}\text { Greater } \\
\text { than 50th } \\
\text { Centile }\end{array}$ & \\
\hline \multirow{2}{*}{$\begin{array}{l}\text { ELBW } \\
\text { Babies }\end{array}$} & Count & 19 & 9 & 2 & 30 \\
\hline & $\%$ & $73.1 \%$ & $47.4 \%$ & $13.3 \%$ & $50.0 \%$ \\
\hline \multirow{2}{*}{$\begin{array}{l}\text { VLBW } \\
\text { Babies }\end{array}$} & Count & 7 & 10 & 13 & 30 \\
\hline & $\%$ & $26.9 \%$ & $52.6 \%$ & $86.7 \%$ & $50.0 \%$ \\
\hline \multirow{2}{*}{ Total } & Count & 26 & 19 & 15 & 60 \\
\hline & $\%$ & $100.0 \%$ & $100.0 \%$ & $100.0 \%$ & $100.0 \%$ \\
\hline \multicolumn{6}{|c|}{ Table 6. Weight at 12 Months of Age } \\
\hline
\end{tabular}

$X^{2}=13.65 ; p=.001(p<0.05) ; d f=2$

Table 6 shows that there is a significant difference between the two groups in weight at 12 months of age. Pvalue, $\mathrm{p}=.001(\mathrm{p}<0.05) ; \mathrm{df}=2$. At 12 months corrected age, babies who weighed less than $3^{\text {rd }}$ centile consisted of $73.1 \%$ of ELBW babies and 26.9\% of VLBW babies. Among those who weighed between $3^{\text {rd }}$ and $50^{\text {th }}$ centile, $47.4 \%$ were ELBW babies and $52.6 \%$ were VLBW babies. Babies who weighed more than $50^{\text {th }}$ centile consisted of $13.3 \%$ ELBW and $86.7 \%$ of VLBW babies.

\begin{tabular}{|c|c|c|c|c|c|}
\hline \multirow[b]{2}{*}{ Group } & & \multicolumn{3}{|c|}{ Length at $3 \mathrm{~m}$} & \multirow[b]{2}{*}{ Total } \\
\hline & & $\begin{array}{c}<3 \text { rd } \\
\text { Centile }\end{array}$ & $\begin{array}{c}\text { 3rd to } \\
50^{\text {th }} \\
\text { Centile }\end{array}$ & $\begin{array}{l}\text { Greater } \\
\text { than } \\
50^{\text {th }} \\
\text { Centile }\end{array}$ & \\
\hline \multirow{2}{*}{$\begin{array}{l}\text { ELBW } \\
\text { Babies }\end{array}$} & Count & 14 & 10 & 6 & 30 \\
\hline & $\%$ & $73.7 \%$ & $50.0 \%$ & $28.6 \%$ & $50.0 \%$ \\
\hline \multirow{2}{*}{$\begin{array}{l}\text { VLBW } \\
\text { Babies }\end{array}$} & Count & 5 & 10 & 15 & 30 \\
\hline & $\%$ & $26.3 \%$ & $50.0 \%$ & $71.4 \%$ & $50.0 \%$ \\
\hline \multirow{2}{*}{ Total } & Count & 19 & 20 & 21 & 60 \\
\hline & $\%$ & $100.0 \%$ & $100.0 \%$ & $100.0 \%$ & $100.0 \%$ \\
\hline \multicolumn{6}{|c|}{ Table 7. Length at 3 Months of Age } \\
\hline
\end{tabular}

$\mathrm{X}^{2}=8.12 ; \mathrm{p}=.017(\mathrm{p}<0.05) ; \mathrm{df}=2$

Table 7 shows that there is a significant difference between the two groups in length at 3 months of age. $P$ value, $p=.017$ $(p<0.05) ; d f=2$. At 3 months of corrected age, babies whose length is less than $3^{\text {rd }}$ centile consisted of $73.7 \%$ of ELBW babies and $26.3 \%$ of VLBW babies. Among those whose length was between $3^{\text {rd }}$ and $50^{\text {th }}$ centile, 50 were ELBW babies and $50 \%$ were VLBW babies. Babies whose length is more than $50^{\text {th }}$ centile consisted of $28.6 \%$ ELBW and $71.4 \%$ of VLBW babies.

\begin{tabular}{|c|c|c|c|c|c|}
\hline \multirow[b]{2}{*}{ Group } & & \multicolumn{3}{|c|}{ Length at $12 \mathrm{~m}$} & \multirow[b]{2}{*}{ Total } \\
\hline & & $\begin{array}{c}<3 \text { rd } \\
\text { Centile }\end{array}$ & $\begin{array}{c}3 \text { rd to } \\
50^{\text {th }} \\
\text { Centile }\end{array}$ & $\begin{array}{c}\text { Greater } \\
\text { than } \\
50^{\text {th }} \\
\text { Centile }\end{array}$ & \\
\hline \multirow{2}{*}{$\begin{array}{l}\text { ELBW } \\
\text { Babies }\end{array}$} & Count & 14 & 8 & 8 & 30 \\
\hline & $\%$ & $53.8 \%$ & $40.0 \%$ & $57.1 \%$ & $50.0 \%$ \\
\hline \multirow{2}{*}{$\begin{array}{l}\text { VLBW } \\
\text { Babies }\end{array}$} & Count & 12 & 12 & 6 & 30 \\
\hline & $\%$ & $46.2 \%$ & $60.0 \%$ & $42.9 \%$ & $50.0 \%$ \\
\hline \multirow{2}{*}{ Total } & Count & 26 & 20 & 14 & 60 \\
\hline & $\%$ & $100.0 \%$ & $100.0 \%$ & $100.0 \%$ & $100.0 \%$ \\
\hline
\end{tabular}

$\mathrm{X}^{2}=1.24 ; \mathrm{p}=.538(\mathrm{p}>0.05) ; \mathrm{df}=2$

Table 8 shows that there is no significant difference between the two groups in length at 12 months of age. $P=.538$ ( $p>0.05) ; d f=2$. At 12 months of age, babies whose length is less than $3^{\text {rd }}$ centile consisted of $53.8 \%$ of ELBW babies and $46.2 \%$ of VLBW babies. Among those whose length was between $3^{\text {rd }}$ and $50^{\text {th }}$ centile, $40 \%$ were ELBW babies and $60 \%$ were VLBW babies. Babies whose length is more than $50^{\text {th }}$ centile consisted of 57.15 ELBW and $42.9 \%$ of VLBW babies.

\begin{tabular}{|c|c|c|c|c|c|}
\hline \multirow[b]{2}{*}{ Group } & & \multicolumn{3}{|c|}{ Head Circumference $3 \mathbf{~ m}$} & \multirow[b]{2}{*}{$\begin{array}{l}\text { Head } \\
\text { Circum } \\
\text { ference }\end{array}$} \\
\hline & & $\begin{array}{l}<1 \text { st } \\
\text { Centile }\end{array}$ & $\begin{array}{c}\text { 3rd to } \\
5^{\text {th }} \\
\text { Centile }\end{array}$ & $\begin{array}{c}5^{\text {th }} \\
\text { Centile }\end{array}$ & \\
\hline \multirow{2}{*}{$\begin{array}{l}\text { ELBW } \\
\text { Babies }\end{array}$} & Count & 12 & 14 & 4 & 30 \\
\hline & $\%$ & $44.4 \%$ & $56.0 \%$ & $50.0 \%$ & $50.0 \%$ \\
\hline \multirow{2}{*}{$\begin{array}{l}\text { VLBW } \\
\text { Babies }\end{array}$} & Count & 15 & 11 & 4 & 30 \\
\hline & $\%$ & $55.6 \%$ & $44.0 \%$ & $50.0 \%$ & $50.0 \%$ \\
\hline \multirow{2}{*}{ Total } & Count & 27 & 25 & 8 & 60 \\
\hline & $\%$ & $100.0 \%$ & $100.0 \%$ & $100.0 \%$ & $100.0 \%$ \\
\hline \multicolumn{6}{|c|}{ Table 9. Head Circumference at 3 Months of Age } \\
\hline
\end{tabular}

$X^{2}=.693 ; p=.707(p>0.05) ; d f=2$.

Table 9 shows that there is no significant difference between the two groups in head circumference at 3 months of age. $P=.707(p>0.05) ; d f=2$. At 3 months of corrected age, babies whose head circumference is less than 1 st centile consisted of $44.4 \%$ of ELBW babies and $55.6 \%$ of VLBW babies. Among those whose head circumference was between $3^{\text {rd }}$ and $50^{\text {th }}$ centile, 56\% were ELBW babies and $44 \%$ were VLBW babies. Babies whose head circumference is more than $50^{\text {th }}$ centile consisted of $50 \%$ ELBW and $50 \%$ of VLBW babies.

\begin{tabular}{|c|c|c|c|c|c|}
\hline \multirow[b]{2}{*}{ Group } & & \multicolumn{3}{|c|}{ Head Circumference $12 \mathrm{~m}$} & \multirow{2}{*}{$\begin{array}{c}\text { Head } \\
\text { Circumference }\end{array}$} \\
\hline & & $\begin{array}{c}<\text { 1st } \\
\text { Centile }\end{array}$ & $\begin{array}{c}\text { 3rd to } \\
50^{\text {th }} \\
\text { Centile }\end{array}$ & $\begin{array}{l}>50^{\text {th }} \\
\text { Centile }\end{array}$ & \\
\hline \multirow{2}{*}{$\begin{array}{l}\text { ELBW } \\
\text { Babies }\end{array}$} & Count & 18 & 8 & 4 & 30 \\
\hline & $\%$ & $54.5 \%$ & $42.1 \%$ & $50.0 \%$ & $50.0 \%$ \\
\hline \multirow{2}{*}{$\begin{array}{l}\text { VLBW } \\
\text { Babies }\end{array}$} & Count & 15 & 11 & 4 & 30 \\
\hline & $\%$ & $45.5 \%$ & $57.9 \%$ & $50.0 \%$ & $50.0 \%$ \\
\hline \multirow{2}{*}{ Total } & Count & 33 & 19 & 8 & 60 \\
\hline & $\%$ & $100.0 \%$ & $100.0 \%$ & $100.0 \%$ & $100.0 \%$ \\
\hline
\end{tabular}

$X^{2}=.746 ; p=.689(p>0.05) ; d f=2$ 
Table 10 shows that there is no significant difference between the two groups in head circumference at 12 months of age; $\mathrm{p}=.689(\mathrm{p}>0.05) ; \mathrm{df}=2$. At 12 months of corrected age, babies whose head circumference is less than 1st centile consisted of $54.5 \%$ of ELBW babies and $45.5 \%$ of VLBW babies. Among those whose head circumference was between $3^{\text {rd }}$ and $50^{\text {th }}$ centile, $42.1 \%$ were ELBW babies and $57.9 \%$ were VLBW babies. Babies whose head circumference is more than $50^{\text {th }}$ centile consisted of $50 \%$ ELBW and $50 \%$ of VLBW babies.

\section{DISCUSSION}

The study was conducted with an objective of comparing the growth of ELBW and VLBW babies till one year of corrected age.

In this study of the total 60 neonates, 30 are ELBW babies and 30 are VLBW babies. In this study, the mean birth weight of ELBW babies is 870 grams and mean birth weight of VLBW babies is $1.2 \mathrm{~kg}$.

In this study there exists a significant difference in the gestational age of babies in the ELBW and VLBW group. In the ELBW group babies, mean gestational age is 29 weeks which is less than the gestational age of babies in VLBW group which is 30.03 weeks.

In a study published in Indian Paediatrics Journal; October 2003 volume about maternal and neonatal profile and immediate outcome in ELBW babies, mean gestational age was 27.8 weeks and mean birth weight was 831 grams. $^{7}$

In another study about the outcome of very low birth weight infants over 3 years report from an Iranian Centre; among VLBW babies mean gestational age was $29.6 \pm 2.5$ weeks; mean birth weight was $1179 \pm 257$ grams. ${ }^{8}$ In another follow-up study of very low birth weight infants born and treated within a perinatal centre. Mean birth weight and gestation was $1066+/-19.3$ gms and $29.5+$ +/- 0.3 weeks, respectively. ${ }^{9}$

\section{a. Discussion on Follow-Up of Weight}

In this study, during follow-up of weight of two groups, there is a significant difference between the two groups in weight at 3 months of age. Among underweight, i.e. $<3^{\text {rd }}$ centile at 3 months of age $25 \%$ was ELBW babies that is 5 babies and $75 \%$ were VLBW babies i.e. 15 babies. Among the babies whose weight fell between $3^{\text {rd }}$ and $50^{\text {th }}$ centile, $57 \%$ were ELBW and 42\% were VLBW. Among the babies who weighed more than $50^{\text {th }}$ centile, $75 \%$ were ELBW and $25 \%$ were VLBW babies.

At 6 months of age, babies who weighed less than $3^{\text {rd }}$ centile consisted of $66.7 \%$ of ELBW babies and $33.3 \%$ of VLBW babies. Among those who weighed between $3^{\text {rd }}$ and $50^{\text {th }}$ centile, $55.6 \%$ were ELBW babies and $44.4 \%$ were VLBW babies. Babies who weighed more than $50^{\text {th }}$ centile consisted of $22.2 \%$ ELBW and $77.8 \%$ VLBW babies, i.e. weight gain was better among the VLBW babies compared to the ELBW group during the period of 3 to 6 months.

At 9 months of age, babies who weighed less than $3^{\text {rd }}$ centile consisted of $72 \%$ of ELBW babies and $28 \%$ of VLBW babies. Among those who weighed between $3^{\text {rd }}$ and $50^{\text {th }}$ centile, $47.4 \%$ were ELBW babies and $52.6 \%$ were VLBW babies. Babies who weighed more than $50^{\text {th }}$ centile consisted of 18.8 ELBW and $81.3 \%$ of VLBW babies.
At 12 months corrected age, babies who weighed less than $3^{\text {rd }}$ centile consisted of $73.1 \%$ of ELBW babies and $26.9 \%$ of VLBW babies. Among those who weighed between $3^{\text {rd }}$ and $50^{\text {th }}$ centile, $47.4 \%$ were ELBW babies and $52.6 \%$ were VLBW babies. Babies who weighed more than $50^{\text {th }}$ centile consisted of $13.3 \%$ ELBW and $86.7 \%$ of VLBW babies.

In another study about growth and neurodevelopmental outcome of VLBW infants at 1 year corrected age after early growth failure, VLBW infants experience a catch up in growth beyond infancy through adolescence. ${ }^{10-14}$

They observed a steady improvement in all anthropometric parameters of VLBW infants from discharge to 12 months. This growth pattern is consistent with findings of other authors, who reported a similar magnitude of improvement in anthropometric Z-scores. ${ }^{11,13}$

\section{b. Discussion on Follow-Up of Head Circumference}

In this study, there exists a significant difference in the head circumference of babies in the ELBW and VLBW group at birth. The ELBW group babies' mean head circumference is $27 \mathrm{~cm}$, which is less than the babies in VLBW group i.e. $28.1 \mathrm{~cm}$.

In this study, but during follow-up there is no significant difference between the two groups in head circumference at 3 months of corrected age. At 3 months of corrected age, babies whose head circumference is less than 1st centile i.e. microcephaly consisted of $44.4 \%$ of ELBW babies and $55.6 \%$ of VLBW babies.

Among those whose head circumference was between $3^{\text {rd }}$ and $50^{\text {th }}$ centile, $56 \%$ were ELBW babies and $44 \%$ were VLBW babies. Babies whose head circumference is more than $50^{\text {th }}$ centile consisted of $50 \%$ ELBW and $50 \%$ of VLBW babies.

At 6 months of age, babies whose head circumference was less than 1st centile consisted of $54.5 \%$ of ELBW babies and $45.5 \%$ of VLBW babies. Among those whose head circumference was between $3^{\text {rd }}$ and $50^{\text {th }}$ centile, $42.1 \%$ were ELBW babies and $57.9 \%$ were VLBW babies. Babies whose head circumference was more than $50^{\text {th }}$ centile consisted of $50 \%$ ELBW and $50 \%$ of VLBW babies, i.e. head growth of VLBW showed improvement over $3^{\text {rd }}$ month to $6^{\text {th }}$ month compared to the ELBW counter parts.

At 9 and 12 months of age, babies whose head circumference was less than 1 st centile consisted of $54.5 \%$ of ELBW babies and $45.5 \%$ of VLBW babies. Among those whose head circumference was between $3^{\text {rd }}$ and $50^{\text {th }}$ centile, 42.1\% were ELBW babies and 57.9\% were VLBW babies. Babies whose head circumference was more than $50^{\text {th }}$ centile consisted of $50 \%$ ELBW and $50 \%$ of VLBW babies.

In this study during the $9^{\text {th }}$ and $12^{\text {th }}$ month assessment of head circumference, the growth continued along the same centiles for both the groups. At 12 months of corrected age, there is no statistical difference in the head circumference between two groups.

\section{c. Discussion on Follow-Up of the Length of the Babies}

In this study, there is a significant difference between the two groups in length at 3 months of age. At 3 months of corrected age, babies whose length was less than $3^{\text {rd }}$ centile consisted of $73.7 \%$ of ELBW babies and $26.3 \%$ of VLBW babies. Among those whose length was between $3^{\text {rd }}$ and $50^{\text {th }}$ centile, 50 were ELBW babies and 50\% were VLBW babies. Babies whose 
length was more than $50^{\text {th }}$ centile consisted of $28.6 \%$ ELBW and $71.4 \%$ of VLBW babies.

There is a significant difference between the two groups in length at 6 months of age. At 6 months of age, babies whose length is less than $3^{\text {rd }}$ centile consisted of $75 \%$ of ELBW babies and $25 \%$ of VLBW babies. Among those whose length was between $3^{\text {rd }}$ and $50^{\text {th }}$ centile, $47.4 \%$ were ELBW babies and $52.6 \%$ were VLBW babies. Babies whose length was more than $50^{\text {th }}$ centile consisted of $28.6 \%$ ELBW and $71.4 \%$ of VLBW babies, i.e. VLBW babies growth was better in terms of length compared to the ELBW counterparts.

At 9 and 12 months of age, babies whose length was less than $3^{\text {rd }}$ centile consisted of $53.8 \%$ of ELBW babies and $46.2 \%$ of VLBW babies. Among those whose length was between $3^{\text {rd }}$ and $50^{\text {th }}$ centile, $40 \%$ were ELBW babies and $60 \%$ were VLBW babies. Babies whose length was more than $50^{\text {th }}$ centile consisted of 57.15 ELBW and $42.9 \%$ of VLBW babies.

\section{CONCLUSION}

- This study with partially retrospective and prospective study design was conducted to compare the growth of ELBW babies versus VLBW babies till one year of corrected age.

- In this study of the total 60 neonates, 30 were ELBW babies and 30 were VLBW babies.

- In this study, the mean birth weight of ELBW babies is 870 grams and the mean birth weight of VLBW babies is $1.2 \mathrm{~kg}$.

- In this study, there exists a significant difference in the Gestational age of babies in the ELBW and VLBW group. In the ELBW group, babies' mean gestational age is 29 weeks which is less than the Gestational age of babies in VLBW group which is 30.03 weeks.

\section{Implication of the Study}

In this study, on comparing two groups, the growth of ELBW babies faltered more compared to their VLBW counterparts during this one year follow-up study. Hence, growth monitoring and early stimulation will be benefitted for both groups, especially for ELBW babies.

\section{Limitation of the Study}

In this study, the subjects were followed up for only one year. Most of the literature shows that the VLBW and ELBW babies does not show catch up growth till 2 years of corrected age. Since the study duration is limited, only limited conclusions can be made on their growth and development.

\section{ACKNOWLEDGEMENTS}

I express my thanks and gratitude to Dr. Savitha P, Professor and HOD, Department of Paediatrics, Government Medical College, Kottayam.

\section{REFERENCES}

[1] World Health Organization, International statistical classification of diseases and related health problems, tenth revision, World Health Organization, Geneva, 1992.

[2] Sullivan MC. Growth trajectories of preterm infants: birth to 12 years. J Pediatr Health Care 2008;22(2):83.

[3] Ford GW, Doyle LW, Davis NM, et al. Very low birth weight and growth into adolescence. Archives in Pediatric and Adolescent Medicine 2000;154(8):77884.

[4] Peralta-Carcelen M, Jackson DS, Goran MI, et al. Growth of adolescents who were born at extremely low birth weight without major disability. Journal of Pediatrics 2000;136(5):633-40.

[5] Powls A, Botting N, Cooke RW, et al. Growth impairment in very low birth weight children at 12 years: correlation with perinatal and outcome variables. Archives of Disease in Childhood 1996;75(3):F152-F7.

[6] Saigal S, Stoskopf BL, Striener DL, et al. Physical growth and current health status of infants who were of extremely low birth weight and controls at adolescence. Pediatrics 2001;108(2):407-15.

[7] Albertsson-Wiklund K, Karlberg J. Natural growth in children born small for gestational age with and without catch-up growth. Acta Paediatrica Suppl 1994;399:64-70.

[8] Afjeh SA, Sabzehei MK, Fallahi M, et al. Outcome of very low birth weight infants over 3 years report from an Iranian Center. Iran J Pediatr 2013;23(5):579-87.

[9] Kumar SP, Anday EK, Sacks LM, et al. Follow-up studies of very low birth weight infants 11,250 grams or less) born and treated within a perinatal center. Pediatrics 1980;66(3):438-44.

[10] Modi M, Saluja S, Kler N, et al. Growth and neurodevelopmental outcome of VLBW Infants at 1 year corrected age. Indian Pediatrics 2013;50(6):5737.

[11] Hack M, Schluchter M, Cartar L, et al. Growth of very low birth weight infants to age 20 years. Pediatrics 2003;112(1 Pt 1):e30-8.

[12] Saluja S, Modi M, Kaur A, et al. Growth of very low birth weight infants during hospital stay. Indian Pediatr 2010;47(10):851-6.

[13] Mackay CA, Ballot DE, Cooper PA. Growth of a cohort of very low birth weight infants in Johannesburg, South Africa. BMC Pediatrics 2011;11:50.

[14] Saigal S, Stoskopf B, Streiner D, et al. Growth trajectories of extremely low birth weight infants from birth to young adulthood: a longitudinal, populationbased study. Pediatr Res 2006;60(6):751-8. 